\title{
SEEDLINGS MORPHOLOGY OF CONFECTIONERY SUNFLOWER AT DIFFERENT pH OF WATER SOLUTION
}

\author{
Ivana VARGA ${ }^{1}$, Jasna ŠOŠTARIĆ ${ }^{1}$, D. ILJKIĆ ${ }^{1}$, \\ Tsvetelina DOBREVA ${ }^{2}$, Manda ANTUNOVIĆ ${ }^{1}$ \\ ${ }^{1}$ Faculty of Agrobiotechnical sciences Osijek \\ Fakultet agrobiotehničkih znanosti Osijek, \\ ${ }^{2}$ Institute of Agriculture, Karnobat, Bulgaria \\ Poljoprivredni institut, Karnobat, Bugarska
}

\section{SUMMARY}

In this study the confectionery sunflower seed was tested to germination at different $\mathrm{pH}$ media, from 3.5 to 8.5. The experiment was set up at room temperature $\left(22^{\circ} \mathrm{C}\right)$ and at $24 \mathrm{~h}$ dark conditions for 10 days. The mean germination rate was $76 \%$. The highest germination rate was $86 \%$ at $\mathrm{pH} 3.5$, whereas the lowest was $68 \%$ at $\mathrm{pH} 5.5$. The ANOVA resulted with very significant influence of $\mathrm{pH}$ on sunflower seedlings root, stem and total length $(\mathrm{p}<0.001)$. The total length of seedlings was the shortest at acid media $(9.2$ $\mathrm{cm}$ at 3.5$)$ and the longest at alkaline media (12.5 $\mathrm{cm}$ at $\mathrm{pH} 8.5)$. Regression equitations showed that increment of stem or root length and total length have a positive trendline at all $\mathrm{pH}$ levels. It was found that the alkaline water solution has a positive influence on protein sunflower seedlings development, but it would be valuable to found how the seeds would germinate at the field conditions.

Key words: confectionery sunflower, $\mathrm{pH}$, root, stem, seedlings

\section{INTRODUCTION}

Sunflower (Helianthus annuus L.) seeds contains about $20 \%$ of protein and the protein contents of the oil press cakes and meals ranging from 30 to $50 \%$ (Žilić et al., 2010). Processing of confectionery sunflower seeds enables the production of protein flour (isolates and concentrates) for human consumption. It is are most commonly used as a valuable component in production of special breads, biscuits and other products. In the last decades there have been sunflower hybrids with increased protein content. Next tohigh energy values of oil and protein, the core of sunflower is very rich in minerals and vitamins. Sunflower is not only an oil and protein plant, but also an important 
Ivana Varga et al.: Seedlings morphology of confectionery sunflower at different $\mathrm{pH}$ of water solution

honey plant. Genetic variability of different cultivars within a sunflower species offers a valuable tool for breeding work (Luan et al., 2014; Ma et al. 2016; Markulj Kulundžić et al., 2016). Confectionery sunflower due to the increase in protein content is intended primarily for cattle, dairy cows, pigs, sheep and goats, rabbits, poultry and birds. The total content of essential amino acids according to Nenova and Drumeva (2012) was within 31.06\% - 32.33\%.

The optimal sowing date is around mid-April. Sunflower grain, which doesn't have to be fried and can partially replace soy in livestock nutrition. In mixtures with cereals and corn whole grain or ground can be used.

Zengin and Kirbag (2007) at 7-day old sunflower seedlings found that total protein content in seedlings decreased, by $15 \%, 27.5 \%$ and $37.5 \%$ with increasing of $\mathrm{Cu}$ concentrations $\left(0.4,0.5\right.$ and $\left.0.6 \mathrm{mM} \mathrm{CuCl}_{2}\right)$, compared to the control seedlings, respectively.

Environmental factors such as temperature, light, $\mathrm{pH}$, soil moisture are all known to affect seed germination. Önemli (2004) stated that in recent years, insufficient seed germination and seedling emergence in sunflower production areas is a major problem, especially along with poor climatic conditions. Soil acidity has become a major yieldlimiting factor in cropping systems (Antunović et al. 2014; Bukvić et al., 2015; Kovačević et al., 2017; Buranji et al. 2019; Iljkić et al. 2019). Acidity problem is common for most agricultural soils due to intensive monocropping. According to Sutradhar et al. (2014), sunflower has been produced traditionally on soils with nearly neutral $\mathrm{pH}$ (6.5 to 7.5). Thus, with the integration of sunflower into the rotation system, liming acidic soils may now need to be considered within the farmer's management practices.

The aim of this study was to test the germination rate and seedlings morphology of confectionery sunflower at different level of $\mathrm{pH}$ water solutions (3.5 to 8.5).

\section{MATERIAL AND METHODS}

The study was set up in the Laboratory of plant analysis at the Faculty of Agrobiotechnical Sciences Osijek, Republic of Croatia. The germination test of different $\mathrm{pH}$ media was set upat room temperature $\left(22^{\circ} \mathrm{C}\right)$ and at $24 \mathrm{~h}$ dark conditions. The germination test was done according to the International Seed Testing Association - ISTA (ISTA, 2006).There were six different $\mathrm{pH}$ levels of water solution tested: 3.5, $4.5,5.5,6.5,7.5$ and 8.5. The granulated $\mathrm{NaCl}$ was used for the tested water solutions of different molarity. There was $55 \mathrm{ml}$ of water solution added on the filter paper (Munktell, $580 \times 580 \mathrm{~mm}, 80 \mathrm{~g} / \mathrm{qm}$ ) before sowing. The seeds were sown on thewet filter paper(within the filter paper) in 4 replications. Filter paper was then rolled, marked and put into clean plastic bag. Every replication consisted of 100 seeds. After 10 days, the total germination rate (\%) was determined by counting the seeds which had germinated. Then, 20 seedlings per replication were chosen randomly in order to measure the length of the seedlings root, stem and total seedlings length $(\mathrm{cm})$. 
Ivana Varga et al.: Seedlings morphology of confectionery sunflower at different $\mathrm{pH}$ of water solution

The results were transformed into Microsoft Office Excel programme and the statistical analysis was done using SAS Enterprise Guide 7.1.The grouping means was done by the Fisher LSD method at $95 \%$ confidence.

\section{RESULTS AND DISCUSSION}

The seedlings germinated differently among the $\mathrm{pH}$ levels. Thus, the mean germination rate of seeds was $76 \%$ (Figure 1). The germination rate varied from $68 \%$ at $\mathrm{pH} 5.5$ up to $86 \%$ at $\mathrm{pH} 3.5$.

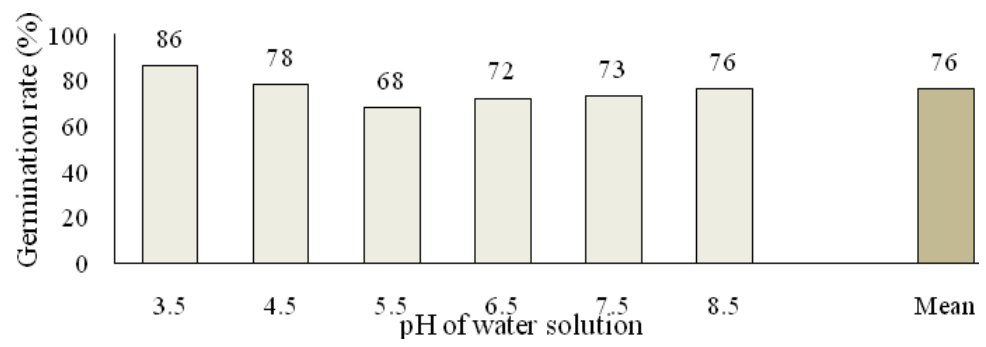

Figure 1 Total germination rate $(\%)$ on the $10^{\text {th }}$ day of confectionery sunflower with regard to $\mathrm{pH}$ of water solution

Slika 1.: Ukupna klijavost (\%) proteinskog suncokreta nakon 10 dana ovisno o pH vrijednosti vodene otopine

The $\mathrm{pH}$ of water solution had a very significant influence $(\mathrm{p}<0.001)$ on confectionery sunflower seedlings morphological parameters (Table 1).

Table 1 The one-way analysis of variance of confectionery sunflower morphological parameters Tablica 1.: Jednosmjerna analiza varijance morfoloških pokazatelja klijanaca proteinskog suncokreta

\begin{tabular}{llll}
\hline & DF & F - value & P - value \\
\hline Root length & 5 & 14.14 & 0.000 \\
Stem length & 5 & 7.86 & 0.000 \\
Total length & 5 & 14.74 & 0.000 \\
\hline
\end{tabular}

Even though in acid media seeds had higher germination rate, the developed seedlings were smallest (Table 2). Mean root length was $4.3 \mathrm{~cm}$ (Table 2). The seedlings in alkaline media of $\mathrm{pH} 8.5$ had the longest root $(5.3 \mathrm{~cm})$ and the shortest root was developed at pH $3.5(3.4 \mathrm{~cm})$. Stem length had the similar trend. The mean stem length was $6.8 \mathrm{~cm}$, while the seedlings at $\mathrm{pH} 8.5(7.2 \mathrm{~cm})$ had the longest stem, and the 
Ivana Varga et al.: Seedlings morphology of confectionery sunflower at different $\mathrm{pH}$ of water solution

seedlings had $\mathrm{pH} 3.5(5.8 \mathrm{~cm})$ shortest stem. Thus the total length of seedlings was also the shortest at acid media $(9.2 \mathrm{~cm})$ and the longest at alkaline media $(12.5 \mathrm{~cm})$.

Table 2 Morphological characteristic of confectionery sunflower seedlings at different pH of water solution

Tablica 2.: Morfološki pokazatelji klijanaca proteinskog suncokreta ovisno o pH vrijednosti vodene otopine

\begin{tabular}{llll}
\hline $\mathbf{p H}$ & Root length (cm) & Stem length (cm) & Total length (cm) \\
\hline 3.5 & $3.4^{\mathrm{c}}$ & $5.8^{\mathrm{c}}$ & $9.2^{\mathrm{d}}$ \\
4.5 & $3.8^{\mathrm{bc}}$ & $6.8^{\mathrm{ab}}$ & $10.6^{\mathrm{c}}$ \\
5.5 & $4.0^{\mathrm{b}}$ & $7.1^{\mathrm{a}}$ & $11.1^{\mathrm{bc}}$ \\
6.5 & $4.1^{\mathrm{b}}$ & $6.3^{\mathrm{bc}}$ & $10.4^{\mathrm{c}}$ \\
7.5 & $5.0^{\mathrm{a}}$ & $6.5^{\mathrm{b}}$ & $11.5^{\mathrm{b}}$ \\
8.5 & $5.3^{\mathrm{a}}$ & $7.2^{\mathrm{a}}$ & $12.5^{\mathrm{a}}$ \\
\hline Mean & $\mathbf{4 . 3}$ & $\mathbf{6 . 8}$ & $\mathbf{1 0 . 9}$ \\
\hline
\end{tabular}

Means that do not share a letter within a column are significantly different at $\mathrm{p}<0.05$

From the regression equitations it can be seen that increment of stem length and total length (Figure 2) and root length and total length (Figure 3) have a positive trendline at all $\mathrm{pH}$ levels. On average at all $\mathrm{pH}$ levels, for 1 centimetre elongation of total length, the stem length increased from $0.38 \mathrm{~cm}(\mathrm{pH} 4.5)$ to $0.62 \mathrm{~cm}(\mathrm{pH} 8.5)$.
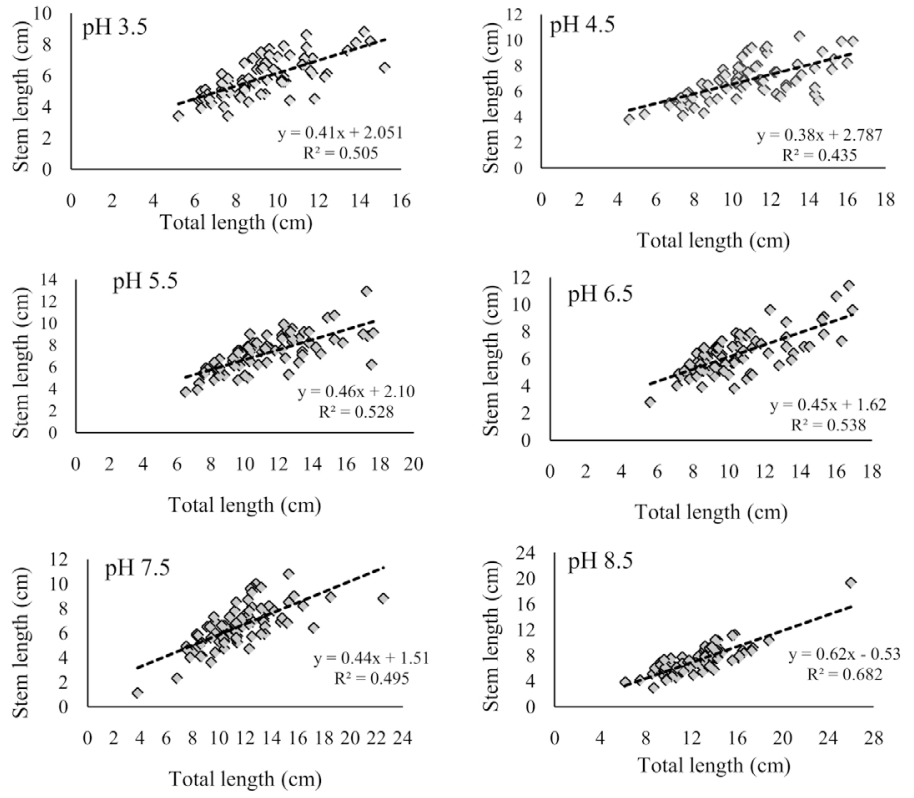

Figure 2 Scatter plot diagrams of confectionery sunflower seedlings stem and total length Slika 2.: Dijagram rasipanja dužine stablike i ukupne dužine klijanaca proteinskog suncokreta 

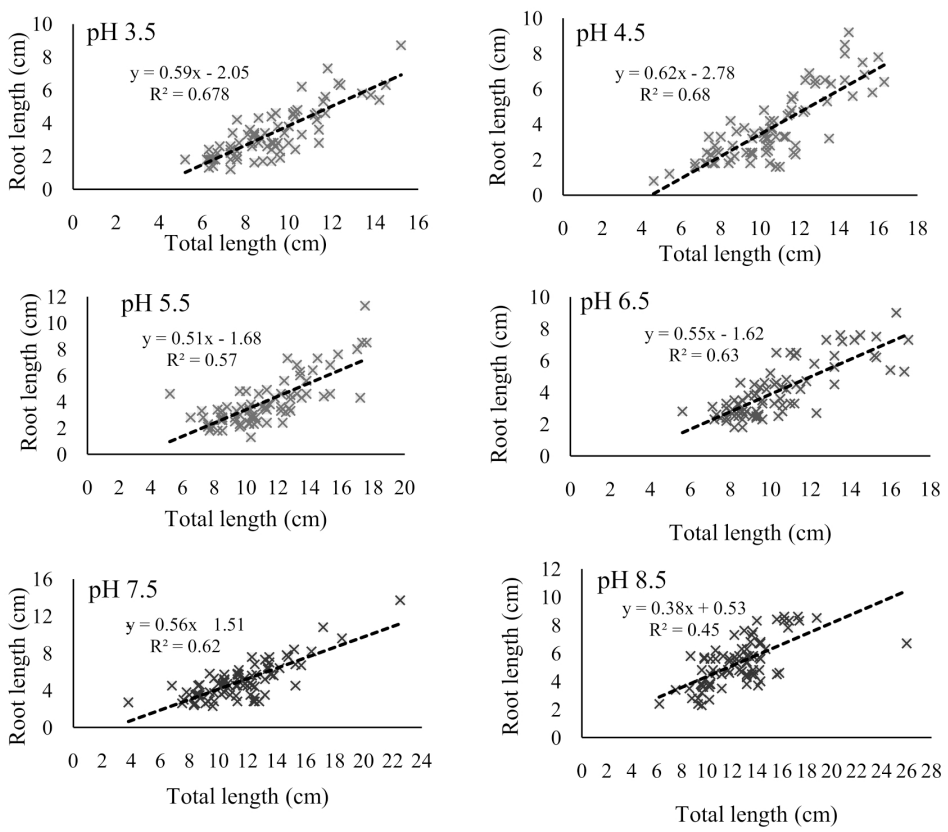

Figure 3 Scatter plot diagrams of confectionery sunflower seedlings root and total length Slika 3.: Dijagram rasipanja dužine korijena i ukupne dužine klijanaca proteinskog suncokreta

The protein content in the seeds of confectionery sunflower is between 17 and $21 \%$ (P o s p i š i 1, 2013). R e u z e a u et al. (1992) try to identify a possible marker for germination capacity and to evaluate seed viability precociously after harvest and after natural ageing during storage of sunflower seed.

$\mathrm{K}$ a $\mathrm{y}$ a et al. (2006) tested sunflower seeds using different seed treatments (control, $\mathrm{KNO}_{3}$ and hydropriming) in salt $(\mathrm{NaCl})$ and drought conditions (PEG 6000) and a significant three-way interaction (seed treatment, solution and stress) was found $(\mathrm{P}<0.05,60$ d.f.) for all investigated characteristic. The authors found that the mean germination rate was decreased with increasing $\mathrm{NaCl}$ level and PEG concentrations, but the lowest germination rate with hydropriming and PEG (25.3\%), while the highest was with $\mathrm{KNO}_{3}$ pre-tretment and is $100 \%$ at all salinity levels. Shoot length after 7 days was from $0.9 \mathrm{~cm}$ (hydropriming and PEG) up to $12.2 \mathrm{~cm}$ (only pre-treatmenthy dropriming).

Yerima et al. (2015) reported about the importance of substrate on germination of sunflower seeds. Authors found that seeds sown in sawdust substrate had the lowest germination rate $(25 \%)$, while in sawdust-soil substrate themaximum germination rate was $75 \%, 9$ days aftersowing.

Önemli (2004) found the highest sunflower seedling emergence percentage $(93.42 \%)$ in glasshouse experiments in which the optimum condition was provided for seed germination and seedling emergence. Autor found that in field conditions the 
Ivana Varga et al.: Seedlings morphology of confectionery sunflower at different $\mathrm{pH}$ of water solution

seedling emergence percentage in $2001(69.87 \%)$ was lower than that in $2000(76.13 \%)$, as total rainfall in 2001 was less than in 2000.

In a experiment, Sutradhar et al. (2014) tested sunflower germination at soil $\mathrm{pH}$ values ranging from 4.0 to 7.0. The authors found that the number of sunflower heads per plot at harvest was reduced in low $\mathrm{pH}$ treatments when compared to the plants number at emergence, which suggested that soil acidity had a strong negative impact on sunflower vegetative growth and yield.

\section{CONCLUSION}

In this study the different level of $\mathrm{pH}$ in confectionery sunflower seed was tested to germination and morphological characteristics of the seedlings. It was found that at low $\mathrm{pH}(3.5,4.5)$ the seedlings were less developed than those in neutral and alkaline media. In the confectionery sunflower, the $\mathrm{pH}$ value also changed the germination rate, but it would be interesting to find out how the seeds would emerge in the field conditions at different levels of soil $\mathrm{pH}$.

\section{MORFOLOŠKE ZNAČAJKE KLIJANACA PROTEINSKOG SUNCOKRETA PRI RAZLIČITIM PH VRIJEDNOSTIMA VODENE OTOPINE}

\section{SAŽETAK}

Cilj ovog istraživanja bio je utvrditi klijavost proteinskog tipa suncokreta na različitim $\mathrm{pH}$ vrijednostima $(3,5$ - 8,5). Eksperiment je postavljen na sobnoj temperaturi $\left(22^{\circ} \mathrm{C}\right)$ i to u mraku $24 \mathrm{~h}$ kroz 10 dana. Ukupna klijavost proteinskog suncokreta bila je $76 \%$. Najviša klijavost iznosila je $86 \%$ pri pH 3,5 , dok je najniža bila $68 \%$ pri pH 5,5. ANOVA je rezultirala vrlo značajnim utjecajem $\mathrm{pH}$ na korijen, stabljiku i ukupnu duljinu klijanaca proteinskog tipa suncokreta $(\mathrm{p}<0,001)$. Ukupna duljina klijanaca bila je najkraća u jako kiseloj sredini $(9,2 \mathrm{~cm}$ kod $\mathrm{pH} 3,5)$, a najduža u alkalnoj sredini $(12,5 \mathrm{~cm}$ kod $\mathrm{pH} 8,5)$. Jednadžba regresije pokazala je da priraštaj duljine stabljike ili korijena i ukupna duljina imaju pozitivan trend na svim $\mathrm{pH}$ razinama. Utvrđeno je da na razvoj klijanaca proteinskog suncokreta pozitivan utjecaj ima alkalna otopina.

Ključne riječi: proteinski suncokret, $\mathrm{NaCl}$, temperatura, klijavost, klijanci 


\section{REFERENCES}

1. Antunović, M., Kovačević, V., Varga, I. (2014): Subsequent effects of liming with carbocalk on maize grain yields. Poljoprivreda, 20(2): 12-18.

2. Bukvić, G., Gantner, R., Grljušić, S., Popović, B., Agić, D., Stanisavljević, A. (2015): Effects of storage period and temperature upon seed and seedling traits of perennial ryegrass (Loliumperenne L.). Poljoprivreda, 21 (2): 3-9.

3. Buranji, I., Varga, I., Lisjak, M., Iljkić, D., Antunović, M., (2019): Morphological characteristic of fiber flax seedlings regard to different $\mathrm{pH}$ water solution and temperature. Journal of Central European Agriculture, 20(4): 1135-1142.

4. Iljkić, D., Kovačević, V., Rastija, M., Antunović, M., Horvat, D., Josipović, M., Varga, I. (2019): Long term effect of Fertdolomite on soil, maize and wheat status on acid soil of eastern Croatia. Journal of Central European Agriculture, 20(1): 461-474.

5. ISTA (2006): ISTA Handbook on Seedling Evaluation. Third edition. The International Seed Testing Association (ISTA). Bassersdorf, Switzerland.

6. Kaya, M. D., Okçu, G., Atak, M., Cıkılı, Y., Kolsarıcı, Ö. (2006): Seed treatments to overcome salt and drought stress during germination in sunflower (Helianthus annuus L.). European journal of agronomy, 24(4): 291-295.

7. Kovačević, V., Antunović, M., Varga, I., Iljkić, D., Jović, J. (2017): Response of soybean and barley to Fertdolomite application on acid soil. Columella: journal of agricultural and environmental sciences, 4(2): 7-15.

8. Luan, Z., Xiao, M., Zhou, D., Zhang, H., Tian, Y., Wu, Y., ... Song, Y. (2014): Effects of salinity, temperature, and polyethylene glycol on the seed germination of sunflower (Helianthus annuus L.). The Scientific World Journal, 2014.

9. Ma, T., Zeng, W., Li, Q., Wu, J., Huang, J. (2016): Effects of water, salt and nitrogen stress on sunflower (Helianthus annuus L.) at different growth stages. Journal of soil science and plant nutrition, 16(4): 1024-1037.

10. Markulj Kulundžić, A., Kovačević, J., Viljevac Vuletić, M., Josipović, A., Liović, I., Mijić, A., Lepeduš, H., Matoša Kočar, M. (2016): Impact of abiotic stress on photosynthetic efficiency and leaf temperature in sunflower. Poljoprivreda, 22(2): 17-22.

11. Nenova, N., Drumeva, M. (2012): Investigation on protein content and amino acid composition in the kernels of some sunflower lines. Helia, 35(56): 41-46.

12. Önemli, F. (2004): The effects of soil organic matter on seedling emergence in sunflower (Helianthus annuus L.). Plant Soil Environ, 50(11): 494-499.

13. Pospišil, M. (2013): Ratarstvo II dio - industrijsko bilje. Zrinski d.d. Čakovec, pp. 169 - 201.

14. Reuzeau, C., Goffner, D., Cavalie, G. (1992): Relation between protein composition and germination capacity of sunflower seeds. Seed Science Research, 2(4): 223-230.

15. Sutradhar, A., Lollato, R. P., Butchee, K., Arnall, D. B. (2014): Determining critical soil pH for sunflower production. International Journal of Agronomy, 2014.Article ID 894196.

16. Yerima, B. P. K., Tiamgne, Y. A., Tziemi, T. C. M. A., Van Ranst, E. (2015): Effect of substrates on germination and seedling emergence of sunflower (Helianthus annuus L.) at the Yongka Western Highlands Research/Garden Park, Bamenda-Cameroon. Tropicultura, 33(2): 91-100.

17. Zengin, F. K., Kirbag, S. (2007): Effects of copper on chlorophyll, proline, protein and abscisic acid level of sunflower (Helianthus annuus L.) seedlings. Journal of Environmental Biology, 28(3): 561.

18. Žilić, S., Barać, M., Pešić, M., Crevar, M., Stanojević, S., Nišavić, A., Saratlić, G., Tolimir, M. (2010): Characterization of sunflower seed and kernel proteins. Helia, 33(52): 103-114. 
Ivana Varga et al.: Seedlings morphology of confectionery sunflower at different $\mathrm{pH}$ of water solution

Adresa autora - Authors' address:

Dr.sc. Ivana Varga,

e-mail: ivana.varga@fazos.hr

Prof.dr.sc. Jasna Šoštarić

Doc.dr.sc. Dario Iljkić

Prof.dr.sc. Manda Antunović

Josip Juraj Strossmayer University of Osijek

Faculty of Agrobiotechnical Sciences Osijek

Department of Crop Production and Biotechnology

Vladimira Preloga 1

31000 Osijek

Croatia

Tsvetelina Dobreva, PhD student

Institute of Agriculture

Industrial Street 1

8400 Karnobat

Bulgaria
Received - Primljeno:

23.07.2020. 